\title{
MORPHOLOGIAL VARIATION IN COLONIES OF Chalara fraxinea ISOLATED FROM ASH (Fraxinus excelsior L.) STEMS WITH SYMPTOMS OF DIEBACK AND EFFECTS OF TEMPERATURE ON COLONY GROWTH AND STRUCTURE
}

\author{
Tadeusz Kowalski, Czesław Bartnik \\ Department of Forest Pathology, Agricultural University, Al. 29-listopada 46, 31-425 Kraków, Poland; \\ e-mail: rltkowal@cyf-kr.edu.pl
}

Received: 1.03 .2010

Abstract

The present paper presents the results of long-term observations of differences in growth and morphology of colonies of $C$. fraxinea isolated from ash stems with symptoms of dieback and the results of studies on effects of temperature on growth and morphology of colonies in vitro. Thirty randomly chosen $C$. fraxinea cultures, originating from six Forest Districts in southern and northern Poland, viz. Andrychów, Gryfice, Kańczuga, Lębork, Miechów and Mircze, were included in the temperature assay. Colony growth and morphology were evaluated in vitro, on malt extract agar. Two replicates of each isolate were incubated at 5, 10, 15, 20,25 and $30^{\circ} \mathrm{C}$ in darkness. Colonies of $C$. fraxinea isolated from necrotic stem tissues of diseased ash trees differed greatly in colour, structure, growth rate, presence of sectors and stromata as well as the intensity of conidial sporulation. Colony characters were often lost in further sub-cultures grown on the same medium. Colonies of $C$. fraxinea grew at $5-25^{\circ} \mathrm{C}$ in vitro. Three isolates still grew, though slowly, at $30^{\circ} \mathrm{C}$. The optimum temperature for growth was $20^{\circ} \mathrm{C}$. Among 30 isolates tested, five grew most quickly at $25^{\circ} \mathrm{C}$ and four at $15^{\circ} \mathrm{C}$. Differences among colony diameters recorded at 5, 10, 15,20 and $30^{\circ} \mathrm{C}$ were statistically significant, while differences at 15 and $25^{\circ} \mathrm{C}$ were not. At some temperatures, statistically significant differences in growth rate were related to the origin of the isolates. There were three main colony colour types. Temperature was the main factor affecting colony morphology in vitro. The formation of sectors was observed in $36 \%$ of colonies, pseudoparenchymatous stromata in $10.4 \%$ of colonies, and white crystalline substances in $53.3 \%$ of colonies. The results of in vitro observations were used for discussion of the effects of temperature on growth and activity of $C$. fraxinea in vivo.

Key words: Fraxinus excelsior, Chalara fraxinea, colonies variability, temperature assay

\section{INTRODUCTION}

The studies on the spectrum of fungi involved in dieback of common ash (Fraxinus excelsior L.) in Poland resulted in identification and description of the novel fungus Chalara fraxinea T. Kowalski (Kow a ls k i, 2006). This fungus was reported from all the forest districts which had been surveyed for the presence of ash trees with dieback symptoms (K ow al $\mathrm{ski}, 2009$ ). The fungus was also found on ash trees with symptoms of dieback in Sweden, Lithuania, Latvia, Denmark, Finland, Germany, Czech Republic, Slovakia, Austria, Hungary, Romania, Slovenia, Switzerland, France, Estonia, and Norway (Zú b r i k and $\mathrm{Kunca}$, 2007; Halmschlager and $\mathrm{Ki}$ risits, 2008; Jankovsky et al. 2008; Szabo, 2008; Drenkhan and Hanso, 2009; Engesser et al. 2009; Ioos et al. 2009; K ow a l s k i, 2009). Initial studies confirmed that the fungus had significant involvement in the process of ash dieback (Bakys et al. 2009; Kirisits et al. 2009; Kowalski and Holdenrieder, 2009a). Therefore, recognition of conditions which favour its growth is required. So far, little is known on this subject ( $\mathrm{K}$ irisits et al. 2008; Kowalski and Holdenrieder, 2009b; $\mathrm{Schumacher}$ et al. 2009).

This paper presents the results of long-term observations on differences in morphology and in vitro growth of $C$. fraxinea colonies isolated from ash stems with symptoms of dieback, and of studies on effects of temperature on colony morphology and growth.

\section{MATERIALS AND METHODS}

Chalara fraxinea was isolated in 2000-2008 from local necrotic lesions and dead stems of ash (Fraxinus excelsior L.) trees sampled in different regions of 
Poland (Kowalski, 2009). Pieces of stem were surface-sterilized by rinsing in $96 \%$ ethanol ( $1 \mathrm{~min}), 4 \%$ $\mathrm{NaOCl}(5 \mathrm{~min})$ and $96 \%$ ethanol (30 sec). After drying in sterile blotting paper and removing surface bark, $5 \mathrm{x}$ $2 \times 2 \mathrm{~mm}$ fragments of tissue were cut off and placed in Petri dishes on the surface of $2 \%$ malt extract agar (MEA; $20 \mathrm{~g}^{-1}$ malt extract Difco, Sparks, MD, USA, $15 \mathrm{~g}^{\prime} \mathrm{l}^{-1}$ agar Difco supplemented with $100 \mathrm{mg}^{\prime} \mathrm{l}^{-1}$ streptomycin sulphate). Growing mycelium was transferred onto $2 \%$ MEA slopes and incubated at $20^{\circ} \mathrm{C}$ in darkness. The growth and morphological characters of the initial colonies growing from the tissues in different conditions of incubation were observed meanwhile. Numerous sub-cultures of $C$. fraxinea originating from morphologically different colony sectors were made and observed. The outcomes of interactions between colonies of $C$. fraxinea and other fungi isolated at the same time were also recorded. Only the most distinctive morphological characters are described here and used to differentiate colonies of $C$. fraxinea.

Thirty randomly chosen cultures of $C$. fraxinea were included in the temperature assay. They were isolated from ash trees in four Forest Districts in southern Poland, viz. Andrychów (No. 1118, 1122, 1130, 1133, 1135), Kańczuga (1001, 1002, 1004, 1012, 1030), Miechów $(625,627,628,631,1043)$ and Mircze (721, $725,726,732,738)$, and two Forest Districts in northern Poland, viz. Lębork $(816,818,819,823,825)$ and Gryfice $(1571,1573,1592,1600,1603)$. Inocula used in the temperature assay were produced by growing in Petri dishes on $2 \%$ MEA for 4 weeks at $20^{\circ} \mathrm{C}$ in darkness. Plugs ( $8 \mathrm{~mm}$ diam) taken from the edge of an actively growing colony were transferred onto $2 \%$ MEA in Petri dishes. The colonies were incubated for 5 weeks at $5,10,15,20,25$ and $30^{\circ} \mathrm{C}$. Growth rate was evaluated on the basis of colony diameter $(\mathrm{mm})$. Two replicates were used for each combination. An average diameter from two measurements in both replicates was estimated. Colony morphology was evaluated on the basis of colour, structure, growth rate, presence of sectors with discoloration, of patchy or linear pseudoparenchymatous stromata and of whitish crystalline agglomerations of secondary metabolites. Three main types of colony colour were distinguished: A - hyaline, evenly white or white with grey patches, or sectors; $\mathrm{B}$ - white-orange or white with numerous ferruginous brown patches; $\mathrm{C}$ - ferruginous brown. The results for the effects of temperature on growth of $C$. fraxinea were analysed statistically using Duncan's test at significance level $\alpha=0.05$.

\section{RESULTS}

Chalara fraxinea isolated from stems of ash with symptoms of dieback
Chalara fraxinea isolated from necrotic tissues of ash trees stems with symptoms of dieback formed colonies which differed greatly in colour, growth rate and interactions with the colonies of other fungi. Some isolates produced hyaline colonies with thin aerial mycelium, evenly white or white with grey patches or sectors (type A, Fig. 3). The most commonly occurring isolates produced colonies that were cottony, white to orange or white with ferruginous brown patches scattered irregularly on the surface or concentrated around the inoculum (type B, Fig. 1). Other isolates produced ferruginous brown colonies (type C, Fig. 2). Black, oval or irregular pseudoparenchymatous stromata were produced around the inoculum or on the surface of the older, type A colonies (Fig. 3). They were formed less often in the ferruginous coloured colonies (Fig. 4).

One of the most distinctive characters of $C$. fraxinea colonies was a tendency to form sectors that differed in colour, structure of aerial mycelium and growth rate (as shown on Figs 15-17). The characters of the sectors were often lost in sub-cultures grown in new Petri dishes, on MEA, from mycelium transferred from the sectors of the initial colonies.

There was much variation in frequency and density of conidial sporulation among different isolates. Sometimes sporulation occurred only on or around the inoculum (Figs 7, 8). The formation of numerous phialides and phialoconidia was associated with olive grey or dark grey discoloration of the colonies in the sporulation zone. Discoloration was very distinctive in both white (Figs 7,8) and ferruginous brown colonies (Fig. 9).

Conidial sporulation of $C$. fraxinea was favoured by lower temperatures $\left(5-15^{\circ} \mathrm{C}\right)$. The white ferruginous or ferruginous brown, non-sporulating colonies, when incubated at a higher temperature $\left(20^{\circ} \mathrm{C}\right)$, started to sporulate abundantly after transfer and further incubation at $5^{\circ} \mathrm{C}$. Sporulation appeared along the Petri dish edges in the olive grey discoloured zone (Fig. 10).

The growth rate of $C$. fraxinea colonies was relatively low. During the isolation procedure, $C$. fraxinea colonies were sometimes overgrown by fast growing colonies of other fungi from ash stems. However, the formation of 3-12 mm wide inhibition zones around larger or smaller colonies of $C$. fraxinea was observed more often (Fig. 5). The inhibition zone protected the $C$. fraxinea colony from being overgrown by the fast growing colonies of the species of Alternaria, Epicoccum, Phomopsis or Diplodia, which were also growing from the ash stems with symptoms of dieback. Agglomerations of white crystalline substances produced during incubation were observed in some $C$. fraxinea colonies (Fig. 6). 


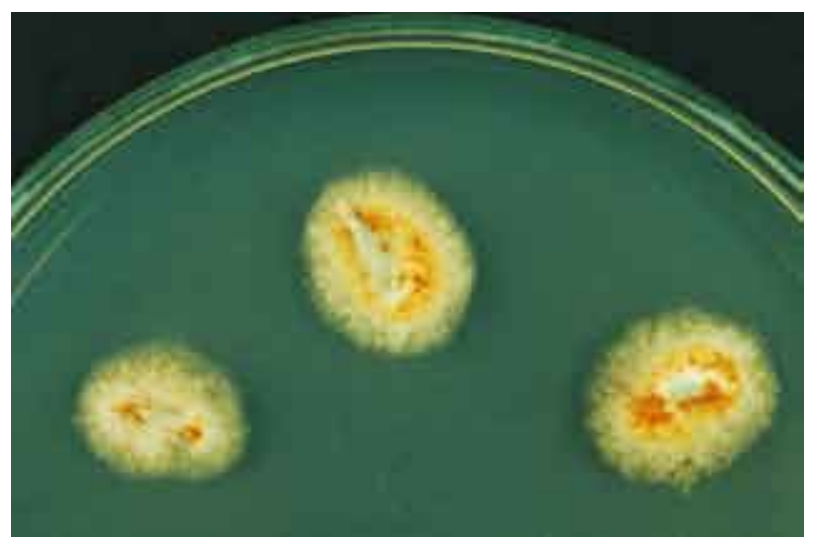

Fig. 1.

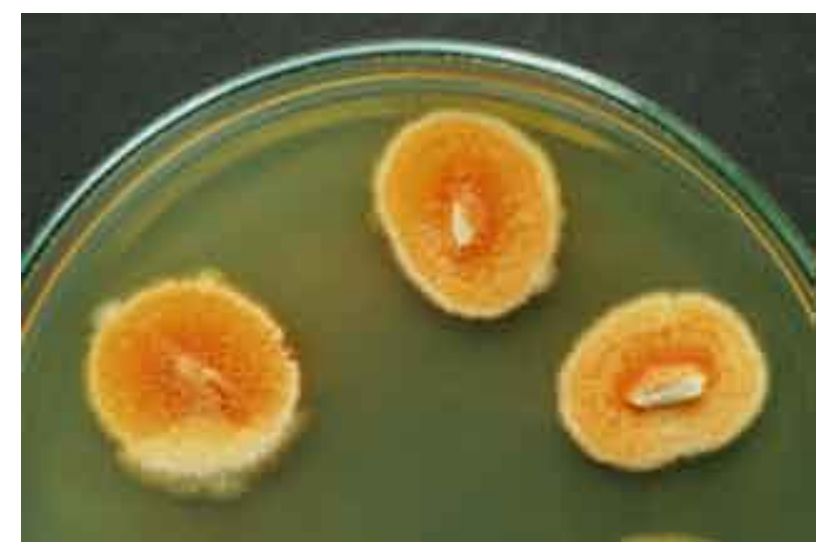

Fig. 2.

Fig. 1-2. Three-week-old cultures of $C$. fraxinea growing from necrotic tissues of stems of ash with symptoms of dieback $\left(20^{\circ} \mathrm{C}\right)$

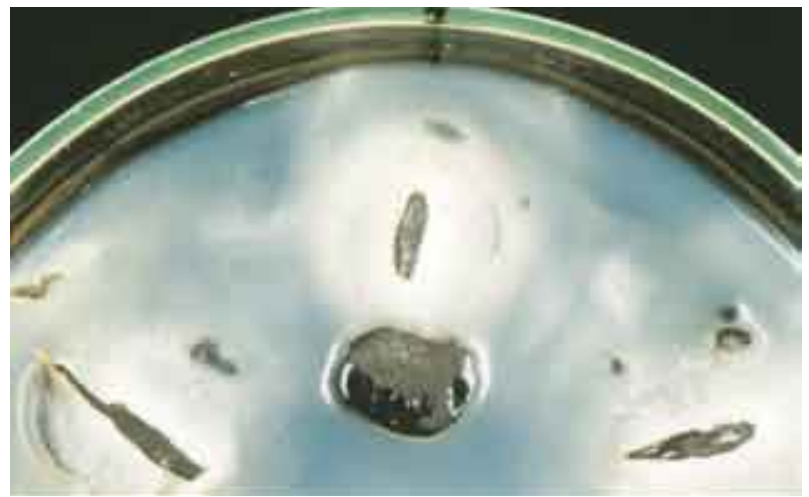

Fig. 3.

Fig. 3-4. Colonies of $C$. fraxinea with stromata $\left(12\right.$ weeks, $\left.15^{\circ} \mathrm{C}\right)$

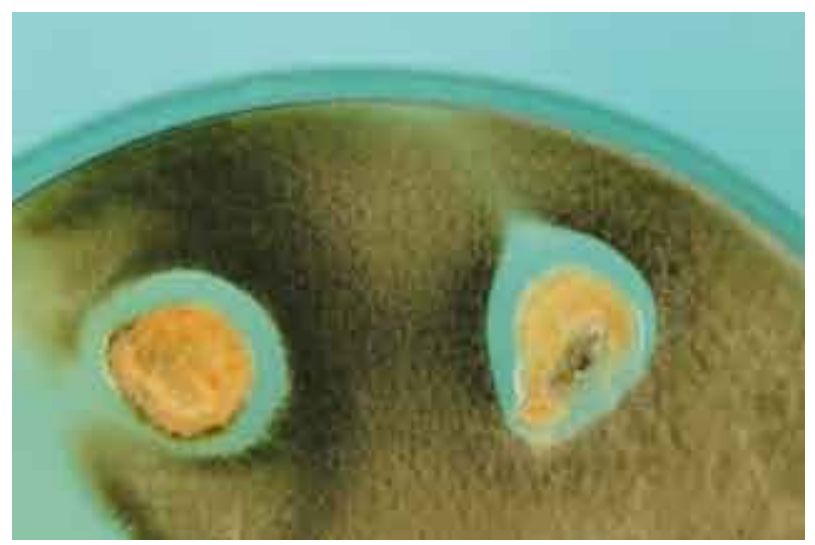

Fig. 5. Inhibition zone between two colonies of $C$. fraxinea and a colony of Alternaria alternata

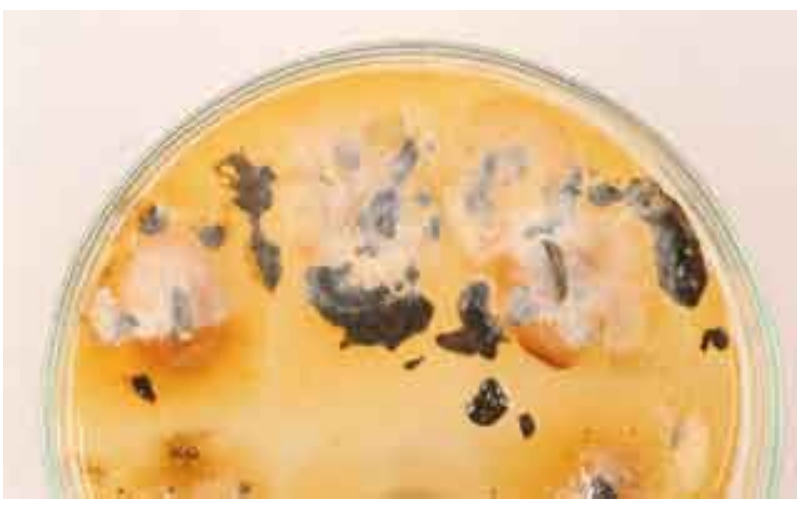

Fig. 4.

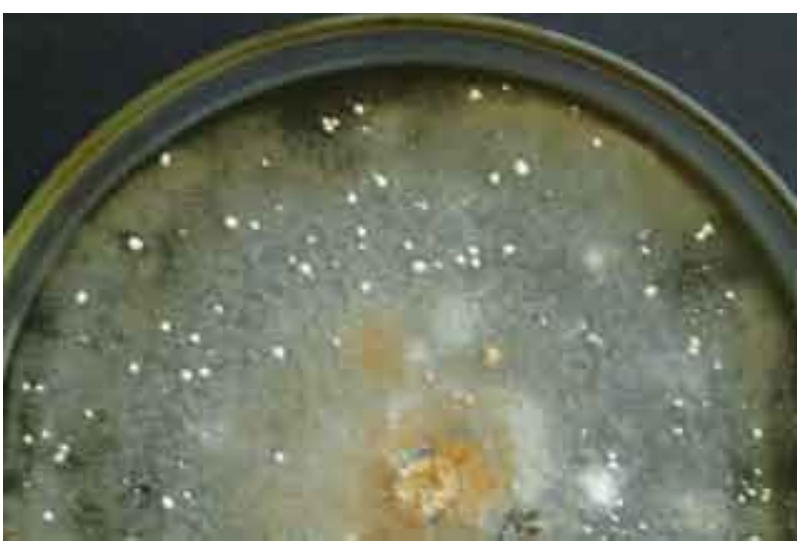

Fig. 6. Colony of $C$. fraxinea with agglomerations of crystalline substances scattered $\left(8\right.$ weeks, $\left.20^{\circ} \mathrm{C}\right)$ 


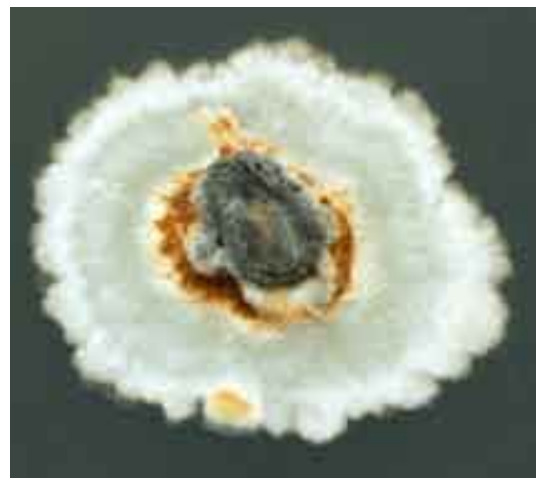

Fig. 7.

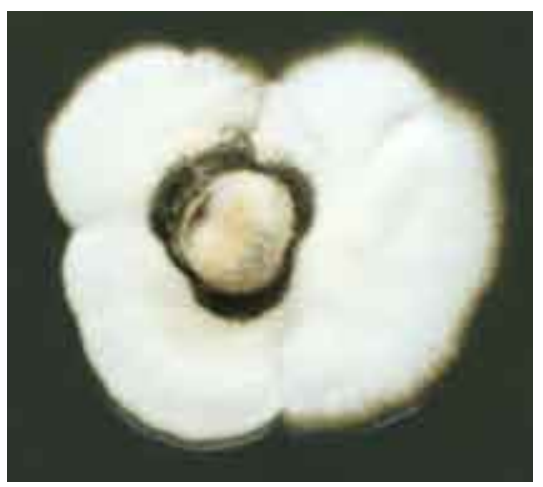

Fig. 8.

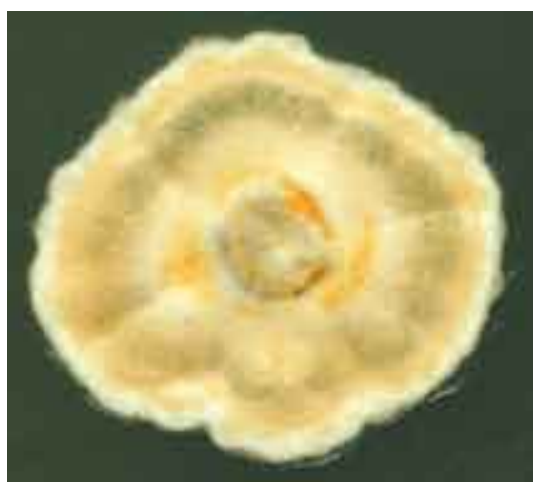

Fig. 9. inoculum, $10^{\circ} \mathrm{C}$, Fig. 8 - sporulation around inoculum, $5^{\circ} \mathrm{C}$, Fig. 9 - sporulation in the form of a ring away from the inoculum, $15^{\circ} \mathrm{C}$

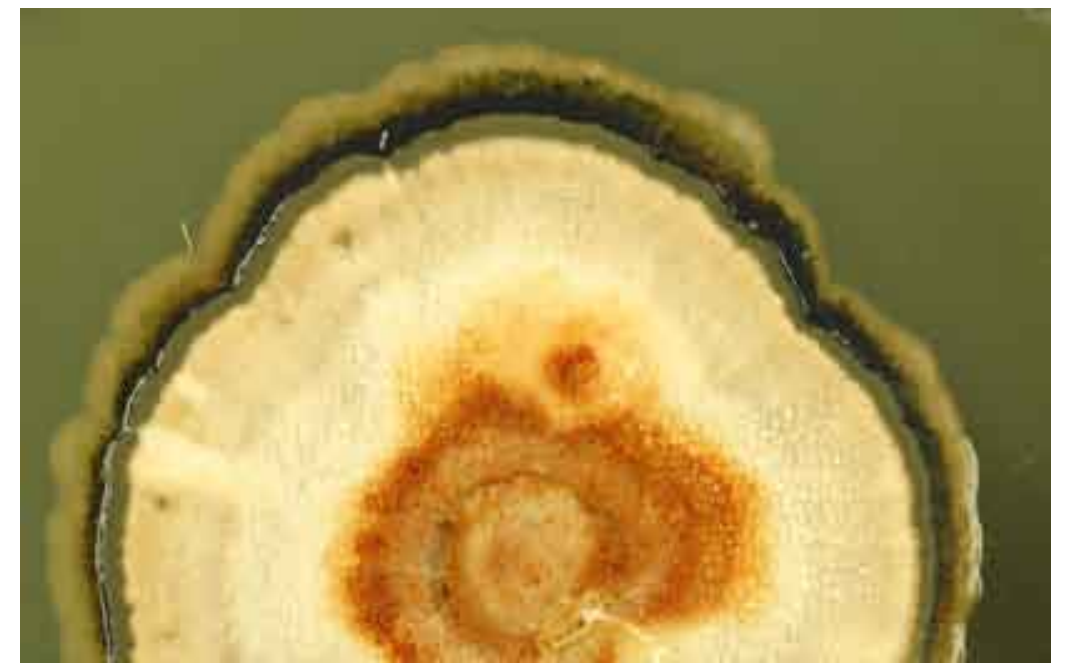

Fig. 10. Colony of $C$. fraxinea after incubation for 4 weeks at $20^{\circ} \mathrm{C}$ followed by 3 weeks at $5^{\circ} \mathrm{C}$ (olive grey ring results from sporulation)

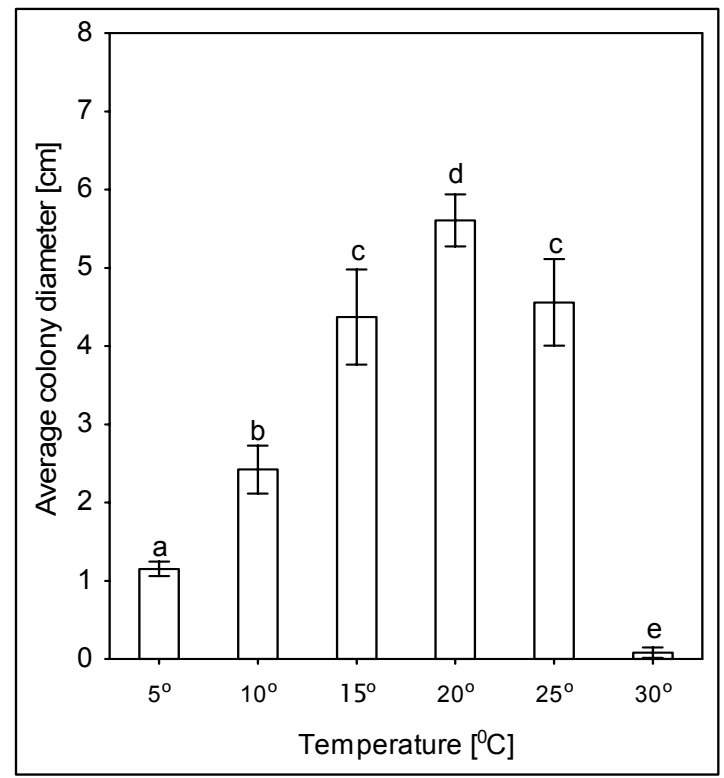

Fig. 11. Growth of C. fraxinea colonies in vitro in relation to temperature (explanation in table 1) 


\section{Temperature assay}

The colonies of $C$. fraxinea grew at $5-25^{\circ} \mathrm{C}$ in vitro. Three isolates of the fungus from Gryfice still grew, though slowly, at $30^{\circ} \mathrm{C}$ (Table 1). Optimum temperature for growth of most isolates was $20^{\circ} \mathrm{C}$ (Fig. 11). Among 30 isolates tested, five grew fastest at $25^{\circ} \mathrm{C}$ (Andrychów No. 1122, Mircze No. 726, Gryfice No. 1592, Kańczuga No. 1004, Lębork No. 819) and four at $15^{\circ} \mathrm{C}$ (Mircze No. 732 and 738, Gryfice No. 1600, Kańczuga No. 1012). Differences among colony diameters recorded at $5,10,20$ and $30^{\circ} \mathrm{C}$ were statistically significant; differences recorded at 15 and $25^{\circ} \mathrm{C}$ were not statistically significant (Fig. 11). At some temperatures, statistically significant differences in growth rate were related to the origin of the isolates (Tab. 1). The smallest differences in growth rate were at 5 and $30^{\circ} \mathrm{C}$, where growth was slowest. The fastest average growth occurred at $10^{\circ} \mathrm{C}$ in isolates from Lębork and Gryfice, at $15^{\circ} \mathrm{C}$ and $25^{\circ} \mathrm{C}$ in the isolates from Lębork and Mircze, and at $20^{\circ} \mathrm{C}$ in isolates from Andrychów, Lębork and Mircze. Significant differences in growth rates among isolates from the same forest district were observed (Tab. 1).

Colony colour of $C$. fraxinea was related to incubation temperature in vitro. Type A was predominant at 5 and $10^{\circ} \mathrm{C}(85.0$ and $75.0 \%$, respectively), type $\mathrm{B}$ at 15 and $20^{\circ} \mathrm{C}(78.3$ and $90.0 \%)$, and type $\mathrm{C}$ at $25^{\circ} \mathrm{C}$ (66.7\%, Tab. 2, Figs 12-14).

Sectors were formed in $36 \%$ of colonies, most often at $15^{\circ} \mathrm{C}(11.0 \%)$ and most rarely at $5^{\circ} \mathrm{C}(4.0 \%)$ (Table 2). In one colony, the sectors differed greatly in colour, structure and growth rate. In the same colony sectors could be ferruginous brown and olive grey (Fig. 15), as well as white with ferruginous brown patches and continuously brown (Fig. 16), or white and dark brown in the ferruginous brown colonies (Fig. 17). Black stromata were formed in $10.4 \%$ of colonies, most often at 5 and $10^{\circ} \mathrm{C}$ (Table 2, Fig. 12). Among 30 isolates tested, 16 produced a whitish crystalline substance located along the entire colony edge, after incubation for 10 weeks at 15 and $20^{\circ} \mathrm{C}$, and in two cases at $25^{\circ} \mathrm{C}$. Five isolates produced this substance very abundantly.

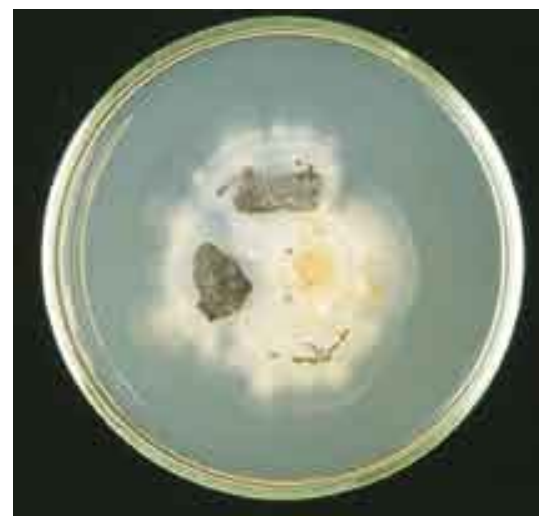

Fig. 12.

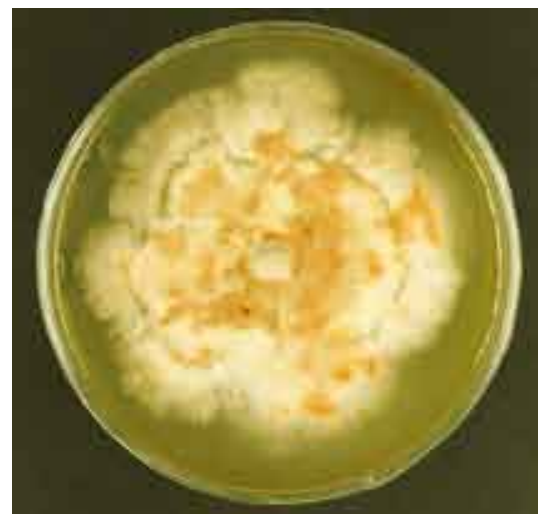

Fig. 13.

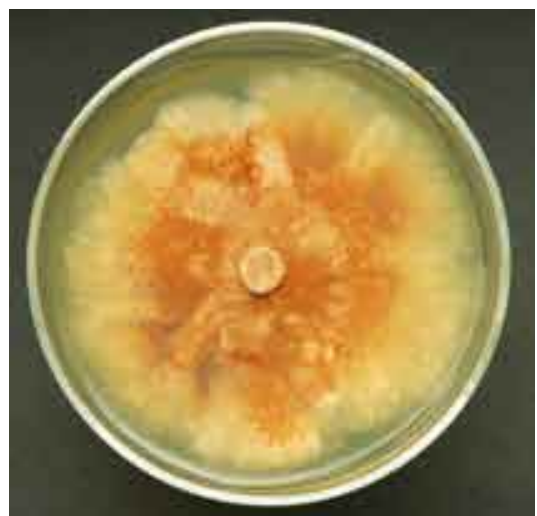

Fig. 14

Fig. 12-14. Different colour types in 5-week-old C. fraxinea colonies: Fig. 12 - Type A $\left(10^{\circ} \mathrm{C}\right)$, Fig. 13 - Type B (20 C), Fig. 14 - Type C $\left(20^{\circ} \mathrm{C}\right)$

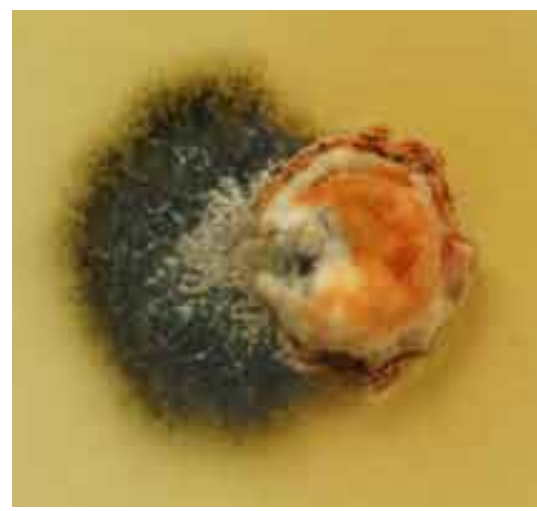

Fig. 15.

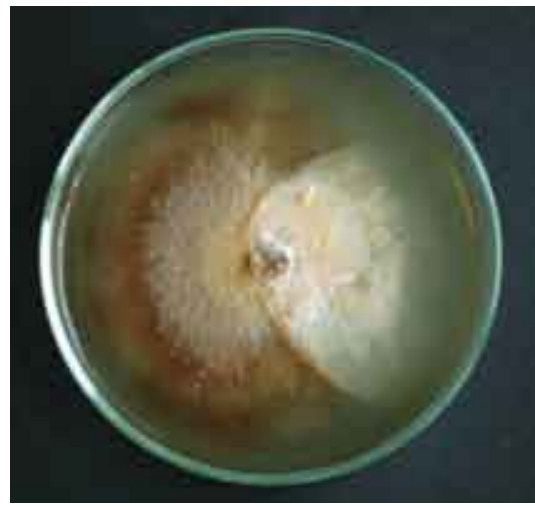

Fig. 16.

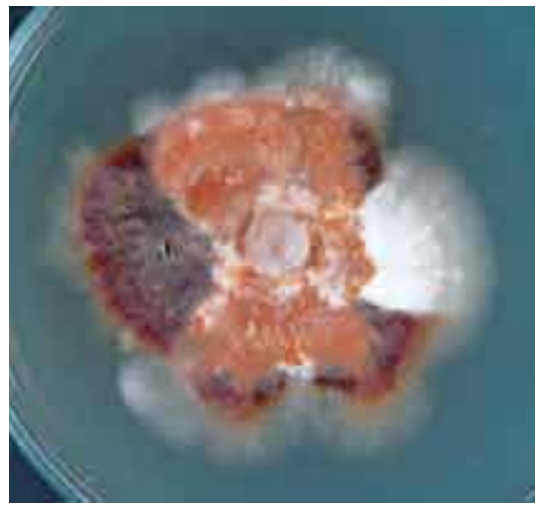

Fig. 17.

Fig. 15-17. Five-week-old C. fraxinea colonies with sectors of different colour, structure and growth rate: Fig. $15-5^{\circ} \mathrm{C}$, Fig. 16 $-20^{\circ} \mathrm{C}$, Fig. $17-25^{\circ} \mathrm{C}$ 
Table 1

Effect of temperature on $C$. fraxinea growth

\begin{tabular}{|c|c|c|c|c|c|c|c|c|c|c|c|}
\hline \multirow{3}{*}{$\begin{array}{c}\text { Origin } \\
\text { Forest District } \\
\text { Andrychów }\end{array}$} & \multicolumn{11}{|c|}{ Colony diameter $(\mathrm{cm})$ at temperature } \\
\hline & \multicolumn{2}{|c|}{$5^{\circ} \mathrm{C}$} & \multicolumn{2}{|l|}{$10^{\circ} \mathrm{C}$} & \multicolumn{2}{|l|}{$15^{\circ} \mathrm{C}$} & \multicolumn{2}{|l|}{$20^{\circ} \mathrm{C}$} & \multicolumn{2}{|l|}{$25^{\circ} \mathrm{C}$} & \multirow{2}{*}{$\frac{30^{\circ} \mathrm{C}}{0,00}$} \\
\hline & $0,95 a^{*}$ & $\pm 0,28 * *$ & $1,47 \mathrm{ab}$ & $\pm 0,60$ & $3,46 \mathrm{c}$ & $\pm 1,17$ & $5,49 \mathrm{~cd}$ & $\pm 1,67$ & $3,61 \mathrm{c}$ & $\pm 1,42$ & \\
\hline Gryfice & $1,68 b$ & $\pm 0,56$ & $3,18 \mathrm{c}$ & $\pm 1,01$ & $4,52 \mathrm{~cd}$ & $\pm 1,88$ & $5,52 \mathrm{~cd}$ & $\pm 0,94$ & $4,90 \mathrm{~cd}$ & $\pm 1,39$ & $0,50 \mathrm{e} \quad \pm 0,46$ \\
\hline Kańczuga & $0,96 \mathrm{a}$ & $\pm 0,18$ & $1,85 \mathrm{ab}$ & $\pm 0,55$ & $3,47 \mathrm{c}$ & $\pm 1,80$ & $3,85 \mathrm{c}$ & $\pm 0,68$ & $3,04 \mathrm{c}$ & $\pm 1,23$ & 0,00 \\
\hline Lębork & $1,16 \mathrm{a}$ & $\pm 0,39$ & $2,89 \mathrm{c}$ & $\pm 1,20$ & $4,78 \mathrm{~cd}$ & $\pm 1,91$ & $6,82 d$ & $\pm 2,04$ & $6,08 \mathrm{~d}$ & $\pm 2,46$ & 0,00 \\
\hline Miechów & $1,00 \mathrm{a}$ & $\pm 0,19$ & $2,04 a b$ & $\pm 0,51$ & $4,18 \mathrm{~cd}$ & $\pm 1,49$ & $5,64 \mathrm{~cd}$ & $\pm 1,77$ & $4,90 \mathrm{~cd}$ & $\pm 1,65$ & 0,00 \\
\hline Mircze & $1,20 \mathrm{a}$ & $\pm 0,27$ & $3,10 \mathrm{c}$ & $\pm 1,12$ & $6,16 \mathrm{~d}$ & $\pm 1,67$ & $6,34 d$ & $\pm 1,74$ & $4,86 \mathrm{~cd}$ & $\pm 2,09$ & 0,00 \\
\hline
\end{tabular}

* - Diameters with the same letter do not differ significantly according to Duncan's test $(\alpha=0.05)$

** - Standard deviation

Table 2

Characters of $C$. fraxinea colonies growing at different temperatures

\begin{tabular}{ccccccc}
\hline & \multicolumn{5}{c}{ Type of colony (number, \%) } \\
\cline { 2 - 5 } Temperature & \multicolumn{2}{c}{ type resulting from colour*1 } & $\begin{array}{c}\text { colonies with } \\
\text { sectors }\end{array}$ & $\begin{array}{c}\text { colonies with } \\
\text { stromata }\end{array}$ & $\begin{array}{c}\text { Number } \\
\text { of colonies }\end{array}$ \\
\cline { 2 - 3 } $55^{\circ} \mathrm{C}$ & $51(85,0)$ & $4(6,7)$ & $5(8,3)$ & $12(4,0)$ & $15(5,0)$ & 60 \\
$10^{\circ} \mathrm{C}$ & $45(75,0)$ & $12(20,0)$ & $3(5,0)$ & $19(6,3)$ & $10(3,3)$ & 60 \\
$15^{\circ} \mathrm{C}$ & $9(15,0)$ & $47(78,3)$ & $4(6,7)$ & $33(11,0)$ & $2(0,7)$ & 60 \\
$20^{\circ} \mathrm{C}$ & $2(3,3)$ & $54(90,0)$ & $4(6,7)$ & $23(7,7)$ & $2(0,7)$ & 60 \\
$25^{\circ} \mathrm{C}$ & $0(0,0)$ & $20(33,3)$ & $40(66,7)$ & $21(7,0)$ & $2(0,7)$ & 60 \\
Total & $107(35,7)$ & $137(45,7)$ & $56(18,6)$ & $108(36,0)$ & $31(10,4)$ & 300 \\
\hline
\end{tabular}

*1 - explanations in Materials and Methods

\section{DISCUSSION}

The colonies of $C$. fraxinea growing in vitro showed considerable variation, particularly in colour, structure, formation of sectors and pseudoparenchymatous stromata. Temperature is one of the main factors that affected colony morphology. The formation of hyaline or white colonies and production of stromata were favoured by lower temperatures, while the formation of more compact, ferruginous brown colonies was favoured by higher temperatures. Colony colour also resulted from the intensity of conidial sporulation, which was favoured by lower temperatures. The colonies became olive grey in the sporulation zones, consistent with observations of Kirisits et al. (2008). Information on morphological variation of $C$. fraxinea colonies can be very useful for quick identification of the pathogen in culture. The formation of sectors in a colony may suggest the presence of more than one fungal species. However, the morphological similarity of sub-cultures growing from inocula taken from particular sectors supports their grouping in a single taxon.

Cardinal temperatures, i.e. minimum, optimum, and maximum, are used to classify fungi as psychrophiles (cold-loving), mesophiles and thermophiles (Griffin, 1981). Chalara fraxinea isolated from necrotic ash-stem tissues should be classified as a mesophile, which generally grows best in moderate temperatures (minimum $>0^{\circ} \mathrm{C}$, maximum $<50^{\circ} \mathrm{C}$, optimum $=15-40^{\circ} \mathrm{C}(\mathrm{G} \mathrm{r}$ i f f i n, 1981). Most isolates grew fastest at $20^{\circ} \mathrm{C}$. There were, however, isolates which grew fastest at $25^{\circ} \mathrm{C}$ or $15^{\circ} \mathrm{C}$. Different temperature preferences are also shown by isolates of other fungal species (J u n g et al. 2001). 
Some of the behaviour modes of $C$. fraxinea in vitro may be explained by its biology in vivo. Phialides and conidia of $C$. fraxinea are produced in vivo on dead ash stems only sporadically (K irisits et al. 2008; Kowalski, 2009; Kowalski and Holdenri e d e r, 2009a). They are, however, produced abundantly on the rachises of fallen leaves, in litter, in autumn, at lower temperatures. The black, stromatal layers of mycelium are formed on rachis of fallen leaves. Pseudoparenchymatous stromata formed in vitro can be an equivalent of the stromatal layers of mycelium formed in vivo (K ow als k i, 2006; $\mathrm{K}$ ir is its et al. 2009; Kowalski and Holdenrieder, 2009b).

The results of recent studies showed that apothecia of Hymenoscyphus pseudoalbidus Queloz et al. (Ascomycota), which was identified as the teleomorph of $C$. fraxinea, are also formed on rachises of fallen leaves (Kowalski and Holdenrieder, 2009b; Queloz et al. 2010). Apothecia appear from July to September. Their occurrence is followed by ascospore discharge, and ascospore germination results in infection of ash trees (K iris its et al. 2009; K ow alski and Holdenrieder, 2009b).

If the optimum temperature for growth of C. fraxinea is usually $20-25^{\circ} \mathrm{C}$ (only sporadically $15^{\circ} \mathrm{C}$ ), the most favourable conditions for growth in vivo occur in summer in the temperate climate of Poland. Colder summer may provide better conditions for isolates with lower temperatures preferences. Extremely hot summers may inhibit the growth of all or most isolates and restrict infection of ash trees. Effects of temperature on growth of the fungus and the effectiveness of infection also occur in other pathogens of forest trees, e.g. Gremmeniella abietina (Lagerb.) M. Morelet, Cenangium ferruginosum Fr., Lophodermium seditiosum Minter, Staley \& Millar and Botrytis cinerea Pers. (B le $\mathrm{n}$ is et al. 1984; D o m a ń s k i and Kowalski, 1988; B ut in, 1996).

Some isolates of $C$. fraxinea produced secondary metabolites in the form of white crystalline substances. Grad et al. (2009) found that this substance includes viridin and viridiol. These compounds are closely related: viridiol is a dihydroderivative of viridin (R e i n o et al. 2008). In nature, the two compounds have different properties. Viridin is highly mycotoxic, with remarkably high activity against certain fungi (Hutchinson, 1999). Viridiol is phytotoxic ( $\mathrm{How}-$ ell and Stipanovic, 1984). Phytotoxic activity of viridiol was observed in ash seedlings, stems and leaves (A nders o n et al. 2010; Grad et al. 2009). Viridin seems responsible for creating the inhibition zones around $C$. fraxinea colonies in mixed cultures. The inhibition zone may protect the $C$. fraxinea colony from being overgrown by fast-growing fungi (Fig. 5), Grad et al. 2009; Kow als ki and Hold en rieder, 2009a).

\section{REFERENCES}

Andersson P. F., Johansson S. B. K., Stenlid J., Broberg A., 2010: Isolation, identification and necrotic activity of viridiol from Chalara fraxinea, the fungus responsible for dieback of ash. Forest Pathology 40: 43-46.

Bakys R., Vasait is R., B arklund P., Ihrmark K., Stenlid J., 2009. Investigations concerning the role of Chalara fraxinea in declining Fraxinus excelsior. Plant Pathology, 58: 284-292

Blen is P. V., Patton R. F., Spear R. N., 1984. Effect of temperature on the ability of Gremmeniella abietina to survive and to colonize host tissue. Eur. J. For. Path. 14: 153-164.

Butin H., 1996. Krankheiten der Wald- und Parkbäume. Diagnose - Biologie - Bekämpfung. G. Thieme Verlag, Stuttgart.

Domański S., Kowalski T., 1988. Untypical die-back of the current seasons shoots of Pinus sylvestris in Poland. Eur. J. For. Path. 18: 157-160.

Drenkhan R., Hanso M., 2009. Common ash decline in Estonia. Eesti Loodus, (in press).

E11 is M. B., E11 is J. P., 1985. Microfungi on Land plants. Slough: Richmond Publ.: 868.

Engesser R., Queloz V., Meier F., Kowalski T., Holden rie der O., 2009. Das Triebsterben der Esche in der Schweiz. Wald und Holz, 6: 24-27.

Grad B., Kowalski T., Kraj W., 2009. Studies on secondary metabolite produced by Chalara fraxinea and its phytotoxic influence on Fraxinus excelsior. Phytopathologia, 54: 61-69.

Griffin D. H., 1981. Fungal Physiology. John Wiley and Sons, New York.

Halmschlager E., Kirisits T., 2008. First report of the ash dieback pathogen Chalara fraxinea on Fraxinus excelsior in Austria. Plant Pathology, 57: 1177.

Howell C. R., Stipanovic R. D., 1984. Phytotoxicity to crop plants and herbicidal effects on weeds of viridiol produced by Gliocladium virens. Phytopathology, 74: 1346-1349.

Hutchin s on C. M., 1999. Trichoderma virens - inoculated composted chicken manure for biological weed control. Biological Control, 16: 217-222.

Ioos R., Kowalski T., Hus son C., Holden rieder O., 2009. Rapid in planta detection of Chalara fraxinea by a real-time PCR assay using a dual-labelled probe. Eur. J. Plant Path. 125: 329-335.

Jankovský L., Palovčiková D., Dvořák M., 2008. Alien diseases of woody plants in the Czech Republic. Forstschutz Aktuell, 44: 32-34.

Jung J. H., Lee S. Y., Lee J. K., 2001, Comparison of Cenangium dieback fungus isolated from three different species of pine. Plant Pathol. J. 17: 216-221.

Kirisits T., Matlakova M., Mottinger-Kroupa S., Halmschlager E., 2008. Verursacht Chalara fraxinea das Zurücksterben der Esche in Österreich?, Forstschutz Aktuell, 43: 29-34. 
Kirisits T., Matlakova M., Mottinger-Kroupa S., Cech T. L., Halm schlager E., 2009. The current situation of ash dieback caused by Chalara fraxinea in Austria. In Doğmuş-Lehtijärvi, T., Proceedings of the conference of IUFRO working party 7.02.02, Eğirdir, Turkey, 11-16.

Kowalski T., 2006. Chalara fraxinea sp. nov. associated with dieback of ash (Fraxinus excelsior) in Poland. For. Path. 36: 264-270.

Kow a 1 sk i T., 2009. Rozprzestrzenienie grzyba Chalara fraxinea w aspekcie procesu chorobowego jesionu w Polsce. / Expanse of Chalara fraxinea fungus in terms of ash dieback in Poland. Sylwan, 10: 668-674.

Kowalski T., Holdenrieder O., 2008. Eine neue Pilzkrankheit an Esche in Europa. Schweiz. Z. Forstwes. 159, 3: 45-50.

Kowalski T., Holden ried e r O., 2009a. Pathogenicity of Chalara fraxinea. For. Path. 39: 1-7.

Kowalski T., Holden rieder O., 2009b. The teleomorph of Chalara fraxinea, the causal agent of ash dieback. For. Path. 39: 304 -308.

Lizon P., 1992. The Genus Hymenoscyphus (Helotiales) in Slovakia, Czechoslovakia. Mycotaxon, 45: 1-59.

Queloz V., Grünig C. R., Berndt R., Kowalski T., Sieber T. N., Holdenrieder O., 2010, Cryptic speciation in Hymenoscyphus albidus. Forest Path. 40, doi: 10.1111/j.1439-0329.2010.00645.x (in press).

Reh m H., 1896. Ascomyceten: Hysteriaceen und Discomyceten. Bd. 3. [In:] Rabenhorst (Hrsg.) Kryptogamen-Flora von Deutschland, Österreich und der Schweiz. Leipzig: Eduard Kummer: 1275.

Reino J. L., Guerrero R. F., Hernández-Galán R., Colla do I. G., 2008. Secondary metabolites from species of the biocontrol agent Trichoderma. Pytochem. Rev. 7: 89-123.

S chu ma cher J., W u lf A., L e o n hard S., 2007a. ErsterNachweis von Chalara fraxinea T. Kowalski sp. nov. in Deutschland - ein Verursacher neuartiger Schäden an Eschen. Nachrichtenbl. Deut. Pflanzenschutzd. 59: 121-123.

S chu m a cher J., Ke h r R., Le o n hard S., 2009. Mycological and histological investigations of Fraxinus excelsior nurserey saplings naturally infected by Chalara fraxinea. For. Path. doi:10.1111/j.1439-0329.2009.00615.x

S z a b o I., 2008. Dieback of common ash (Fraxinus excelsior) caused by Chalara fraxinea in Hungary. Novenyvedelem, 44 (9): 444-446.

Thomsen I. M., Skovsga ard J. P., B arklund P., Vas a it is R., 2007. Fungal disease is the cause of ash dieback. Skoven, 39: 234-6.

Zúbrik M., Kunca A., 2007. Poradňa ochrany lesa. Les/ Slovenské lesokruhy, 63 (9-10): 32-33.
Zróżnicowanie morfologiczne kolonii

Chalara fraxinea wyizolowanych z jesionów

(Fraxinus excelsior L.) z objawami zamierania oraz wpływ temperatury na ich wzrost i strukturę

\section{Streszczenie}

Przedstawiono wyniki wieloletnich obserwacji nad zróżnicowaniem morfologicznym i rozwojem kolonii $C$. fraxinea bezpośrednio izolowanych z pędów jesionu oraz wyniki badań nad wpływem temperatury na wzrost i zróżnicowanie kolonii in vitro. W teście temperaturowym użyto 30 losowo wybranych kultur $C$. fraxinea pochodzących z sześciu nadleśnictw z południowej i północnej Polski: Andrychów, Gryfice, Kańczuga, Lębork, Miechów i Mircze. Wzrost grzybni określano na pożywce agarowo-maltozowej. Dwa powtórzenia każdego izolatu były inkubowane w ciemności w temperaturach: 5, 10, 15, 20, 25 and $30^{\circ} \mathrm{C}$. Dodatkowo odnotowywano inne cechy związane $\mathrm{z}$ morfologią i rozwojem kolonii in vitro.

Kolonie $C$. fraxinea wyrastające $\mathrm{z}$ nekrotycznych tkanek na pędach jesionu cechowała duża zmienność w zakresie barwy, tempa wzrostu, wykształcania sektorów, tworzenia stromata oraz zarodnikowania. Cechy kolonii stosunkowo często nie były odtwarzane w subkulturach hodowanych na tej samej pożywce.

Kolonie $C$. fraxinea wykazywały in vitro wzrost w zakresie temperatur od 5 do $25^{\circ} \mathrm{C}$, a trzy izolaty wzrastały minimalnie także w $30^{\circ} \mathrm{C}$. Optimum wzrostu dla większości szczepów wynosiło $20^{\circ} \mathrm{C}$. Spośród testowanych 30 izolatów, pięć rosło najszybciej w $25^{\circ} \mathrm{C}$, a cztery $\mathrm{w} 15^{\circ} \mathrm{C}$. Stwierdzono statystycznie istotne różnice pomiędzy średnicami kolonii $\mathrm{w}$ temperaturze 5 , $10,15,20$ i $30^{\circ} \mathrm{C}$ oraz brak takich różnic w 15 i $25^{\circ} \mathrm{C}$. W niektórych temperaturach stwierdzono statystycznie istotne różnice $w$ tempie wzrostu kolonii zależnie od miejsca ich pochodzenia. Najmniejsze zróżnicowanie było w tym zakresie w temperaturach 5 i $30^{\circ} \mathrm{C}$, w których wzrost szczepów był najwolniejszy.

Wyróżniono trzy zasadniczo różniące się typy barwne kolonii, których częstość występowania zależała w znacznym stopniu od temperatury hodowli in vitro. Tworzenie sektorów zostało zaobserwowane u 36\% kolonii, wykształcanie pseudoparenchymatycznych stromata u $10.4 \%$, a obecność krystalicznej substancji u 53.3\% kolonii. W dyskusji podjęto próbę odniesienia się do warunków rozwoju sprawcy zamierania jesionu in vivo w świetle uzyskanych wyników in vitro. 